\title{
LEVEL II SCOUR ANALYSIS FOR BRIDGE 22 (WODSTH00180022) on TOWN HIGHWAY 18, crossing NORTH BRIDGEWATER BROOK, WOODSTOCK, VERMONT
}

U.S. Geological Survey Open-File Report 96-159

Prepared in cooperation with

VERMONT AGENCY OF TRANSPORTATION and

FEDERAL HIGHWAY ADMINISTRATION 


\section{LEVEL II SCOUR ANALYSIS FOR BRIDGE 22 (WODSTH00180022) on TOWN HIGHWAY 18, crossing NORTH BRIDGEWATER BROOK, WOODSTOCK, VERMONT \\ By SCOTT A. OLSON}

U.S. Geological Survey Open-File Report 96-159

Prepared in cooperation with

VERMONT AGENCY OF TRANSPORTATION and

FEDERAL HIGHWAY ADMINISTRATION 


\title{
U.S. DEPARTMENT OF THE INTERIOR BRUCE BABBITT, Secretary
}

\author{
U.S. GEOLOGICAL SURVEY \\ Gordon P. Eaton, Director
}

For additional information write to:

District Chief

U.S. Geological Survey 361 Commerce Way

Pembroke, NH 03275-3718
Copies of this report may be purchased from:

U.S. Geological Survey Earth Science Information Center Open-File Reports Section Box 25286, MS 517 Federal Center

Denver, CO 80225 


\section{CONTENTS}

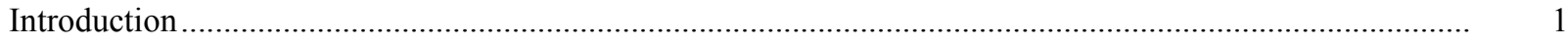

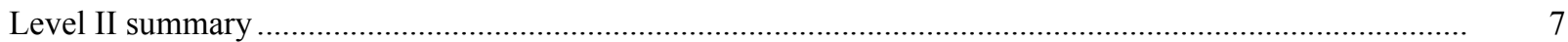

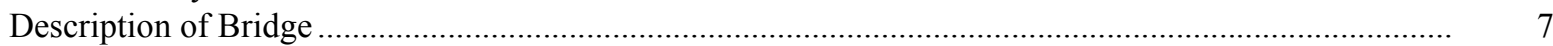

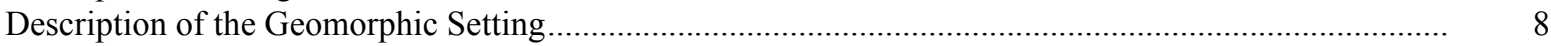

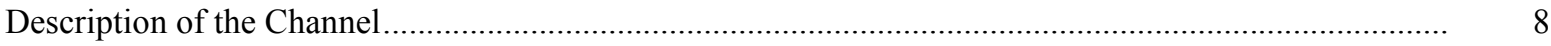

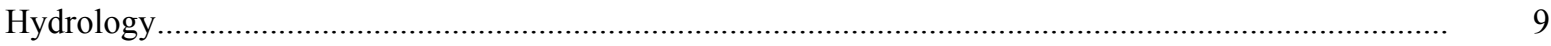

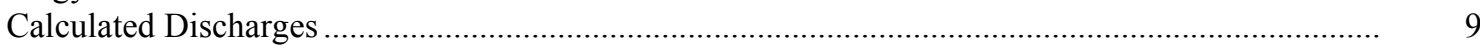

Description of the Water-Surface Profile Model (WSPRO) Analysis ......................................................... 10

Cross-Sections Used in WSPRO Analysis ......................................................................................

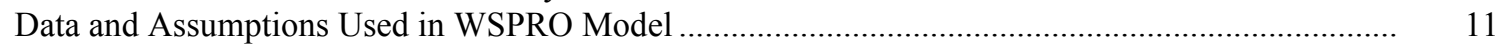

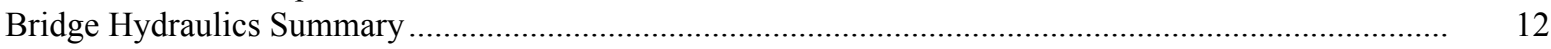

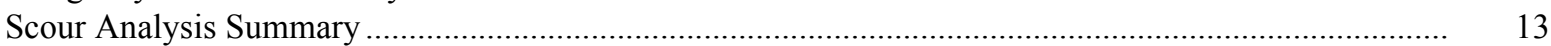

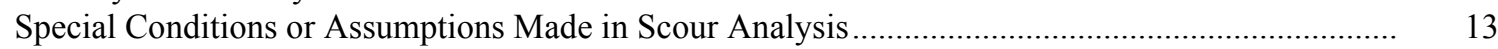

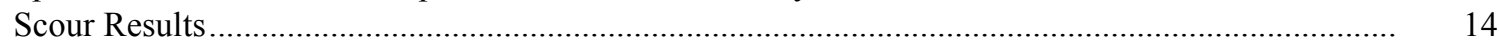

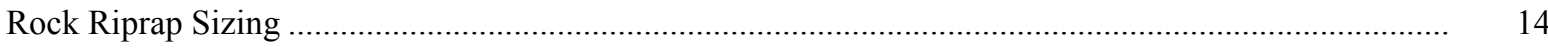

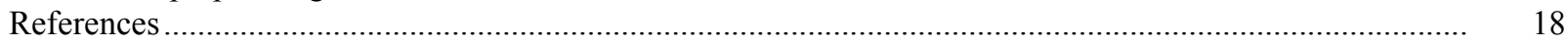

Appendixes:

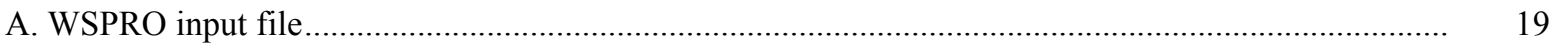

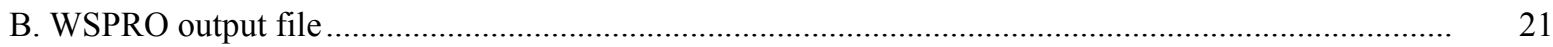

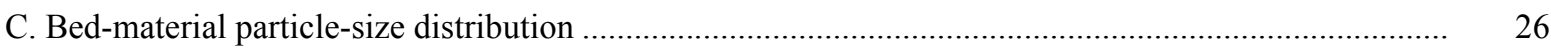

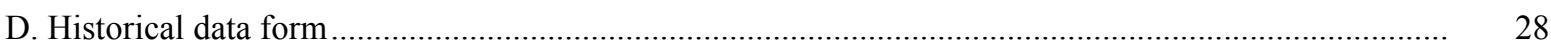

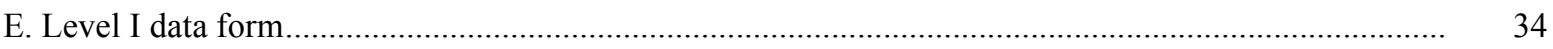

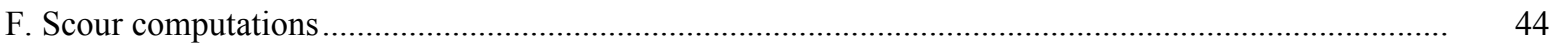

\section{FIGURES}

1. Map showing location of study area on USGS $1: 24,000$ scale map .......................................................

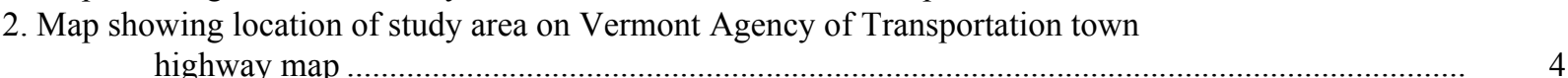

3. Structure WODSTH00180022 viewed from upstream (August 16, 1994) ..................................................... 5

4. Downstream channel viewed from structure WODSTH00180022 (August 16, 1994)............................. 5

5. Upstream channel viewed from structure WODSTH00180022 (August 16, 1994)...................................... 6

6. Structure WODSTH00180022 viewed from downstream (August 16, 1994) ........................................... 6

7. Water-surface profiles for the 100- and 500-year discharges at structure WODSTH00180022 on Town Highway 18, crossing North Bridgewater Brook,

Woodstock, Vermont

8. Scour elevations for the 100 - and 500-year discharges at structure

WODSTH00180022 on Town Highway 18, crossing North Bridgewater Brook,

Woodstock, Vermont.

\section{TABLES}

1. Remaining footing/pile depth at abutments for the 100-year discharge at structure

WODSTH00180022 on Town Highway 18, crossing North Bridgewater Brook,

Woodstock, Vermont

2. Remaining footing/pile depth at abutments for the 500-year discharge at structure

WODSTH00180022 on Town Highway 18, crossing North Bridgewater Brook,

Woodstock, Vermont

6




\begin{tabular}{|c|c|c|}
\hline Multiply & By & To obtain \\
\hline \multicolumn{3}{|c|}{ Length } \\
\hline inch (in.) & 25.4 & millimeter (mm) \\
\hline foot $(\mathrm{ft})$ & 0.3048 & meter $(\mathrm{m})$ \\
\hline mile (mi) & 1.609 & kilometer (km) \\
\hline \multicolumn{3}{|c|}{ Slope } \\
\hline foot per mile ( $\mathrm{ft} / \mathrm{mi})$ & 0.1894 & meter per kilometer $(\mathrm{m} / \mathrm{km})$ \\
\hline \multicolumn{3}{|c|}{ Area } \\
\hline square mile $\left(\mathrm{mi}^{2}\right)$ & 2.590 & square kilometer $\left(\mathrm{km}^{2}\right)$ \\
\hline \multicolumn{3}{|c|}{ Volume } \\
\hline cubic foot $\left(\mathrm{ft}^{3}\right)$ & $\begin{array}{l}0.02832 \\
\text { Velocity and Flow }\end{array}$ & cubic meter $\left(\mathrm{m}^{3}\right)$ \\
\hline foot per second (ft/s) & 0.3048 & meter per second $(\mathrm{m} / \mathrm{s})$ \\
\hline cubic foot per second $\left(\mathrm{ft}^{3} / \mathrm{s}\right)$ & 0.02832 & cubic meter per second $\left(\mathrm{m}^{3} / \mathrm{s}\right)$ \\
\hline $\begin{array}{l}\text { cubic foot per second per } \\
\text { square mile } \\
{\left[\left(\mathrm{ft}^{3} / \mathrm{s}\right) / \mathrm{mi}^{2}\right]}\end{array}$ & 0.01093 & $\begin{array}{l}\text { cubic meter per } \\
\text { second per square } \\
\text { kilometer }\left[\left(\mathrm{m}^{3} / \mathrm{s}\right) / \mathrm{km}^{2}\right]\end{array}$ \\
\hline
\end{tabular}

OTHER ABBREVIATIONS

$\begin{array}{lrlr}\mathrm{BF} & \text { bank full } & \text { LWW } & \text { left wingwall } \\ \mathrm{cfs} & \text { cubic feet per second } & \text { MC } & \text { main channel } \\ \mathrm{D}_{50} & \text { median diameter of bed material } & \text { RAB } & \text { right abutment } \\ \mathrm{DS} & \text { downstream } & \text { RABUT } & \text { face of right abutment } \\ \mathrm{elev} & \text { elevation } & \text { RB } & \text { right bank } \\ \mathrm{f} / \mathrm{p} & \text { flood plain } & \text { ROB } & \text { right overbank } \\ \mathrm{ft} & \text { square feet } & \text { RWW } & \text { right wingwall } \\ \mathrm{ft} / \mathrm{ft} & \text { feet per foot } & \text { TH } & \text { town highway } \\ \mathrm{JCT} & \text { junction } & \text { UB } & \text { under bridge } \\ \mathrm{LAB} & \text { left abutment } & \text { US } & \text { upstream } \\ \mathrm{LABUT} & \text { face of left abutment } & \text { USGS } & \text { United States Geological Survey } \\ \text { LB } & \text { left bank } & \text { VTAOT Vermont Agency of Transportation } \\ \text { LOB } & \text { left overbank } & \text { WSPRO } & \text { water-surface profile model }\end{array}$

In this report, the words "right" and "left" refer to directions that would be reported by an observer facing downstream. Sea level: In this report, "sea level" refers to the National Geodetic Vertical Datum of 1929-- a geodetic datum derived from a general adjustment of the first-order level nets of the United States and Canada, formerly called Sea Level Datum of 1929.

In the appendices, the above abbreviations may be combined. For example, USLB would represent upstream left bank. 


\title{
LEVEL II SCOUR ANALYSIS FOR BRIDGE 22 (WODSTH00180022) ON TOWN HIGHWAY 18, CROSSING NORTH BRIDGEWATER BROOK, WOODSTOCK, VERMONT
}

\author{
By Scott A. Olson
}

\section{INTRODUCTION}

This report provides the results of a detailed Level II analysis of scour potential at structure WODSTH00180022 on town highway 18 crossing North Bridgewater Brook, Woodstock, Vermont (figures 1-8). A Level II study is a basic engineering analysis of the site, including a quantitative analysis of stream stability and scour (U.S. Department of Transportation, 1993). A Level I study is included in Appendix E of this report. A Level I study provides a qualitative geomorphic characterization of the study site. Information on the bridge, available from VTAOT files, was compiled prior to conducting Level I and Level II analyses and can be found in Appendix D.

The site is in the Green Mountain physiographic province of central Vermont. The 4.34-mi ${ }^{2}$ drainage area is in a predominantly rural and forested basin. In the vicinity of the study site, the left bank is forested and the right bank is covered by shrub and brush and is adjacent to woods. The right bank of North Bridgewater Brook is parallel to town highway 18 upstream of the bridge. 
In the study area, North Bridgewater Brook has a sinuous channel with a slope of approximately $0.038 \mathrm{ft} / \mathrm{ft}$, an average channel top width of $48 \mathrm{ft}$ and an average channel depth of $7 \mathrm{ft}$. The predominant channel bed materials are gravel and cobbles $\left(\mathrm{D}_{50}\right.$ is 63.2 $\mathrm{mm}$ or $0.207 \mathrm{ft}$ ). Due to cut banks and other channel features the geomorphic assessment at the time of the Level I and Level II site visit on August 16, 1994, indicated that the reach was laterally unstable. In addition, the stream approach to the bridge has a high gradient. However, near the upstream face of the bridge the gradient shallows. Approximately 100 feet downstream of the bridge the gradient steepens again.

The town highway 18 crossing of North Bridgewater Brook is a 40-ft-long, two-lane bridge consisting of one 35-foot concrete span (Vermont Agency of Transportation, written commun., August 2, 1994). The bridge is supported by vertical, concrete abutments with wingwalls. The left and right abutments are not protected by stone fill. Additional details describing conditions at the site are included in the Level II Summary and Appendices D and $\mathrm{E}$.

Scour depths and rock rip-rap sizes were computed using the general guidelines described in Hydraulic Engineering Circular 18 (Richardson and others, 1993). Scour depths were calculated assuming an infinite depth of erosive material and a homogeneous particle-size distribution. The scour analysis results are presented in tables 1 and 2 and a graph of the scour depths is presented in figure 8. 


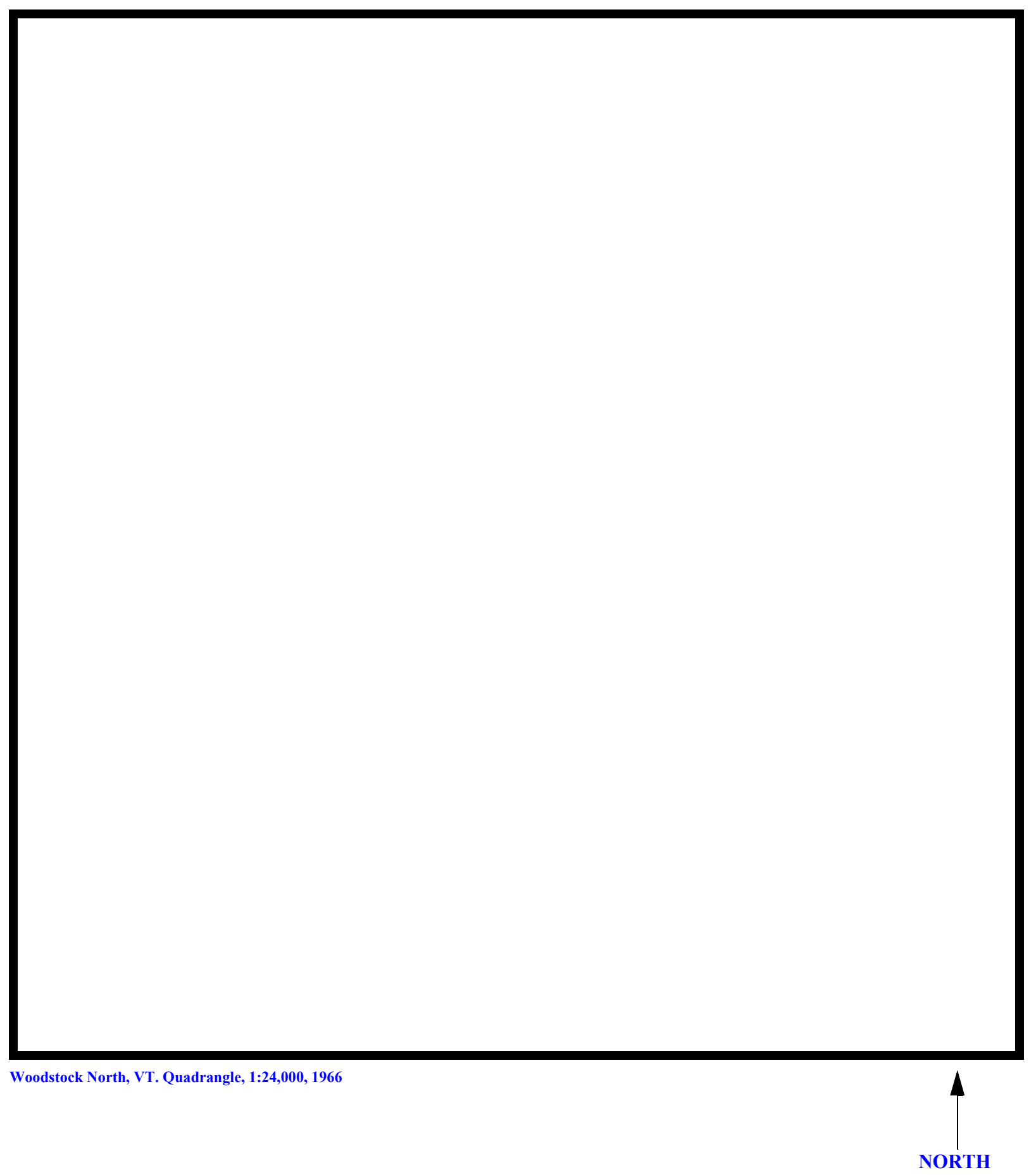

Figure 1. Location of study area on USGS 1:24,000 scale map. 
Figure 2. Location of study area on Vermont Agency of Transportation town highway map. 

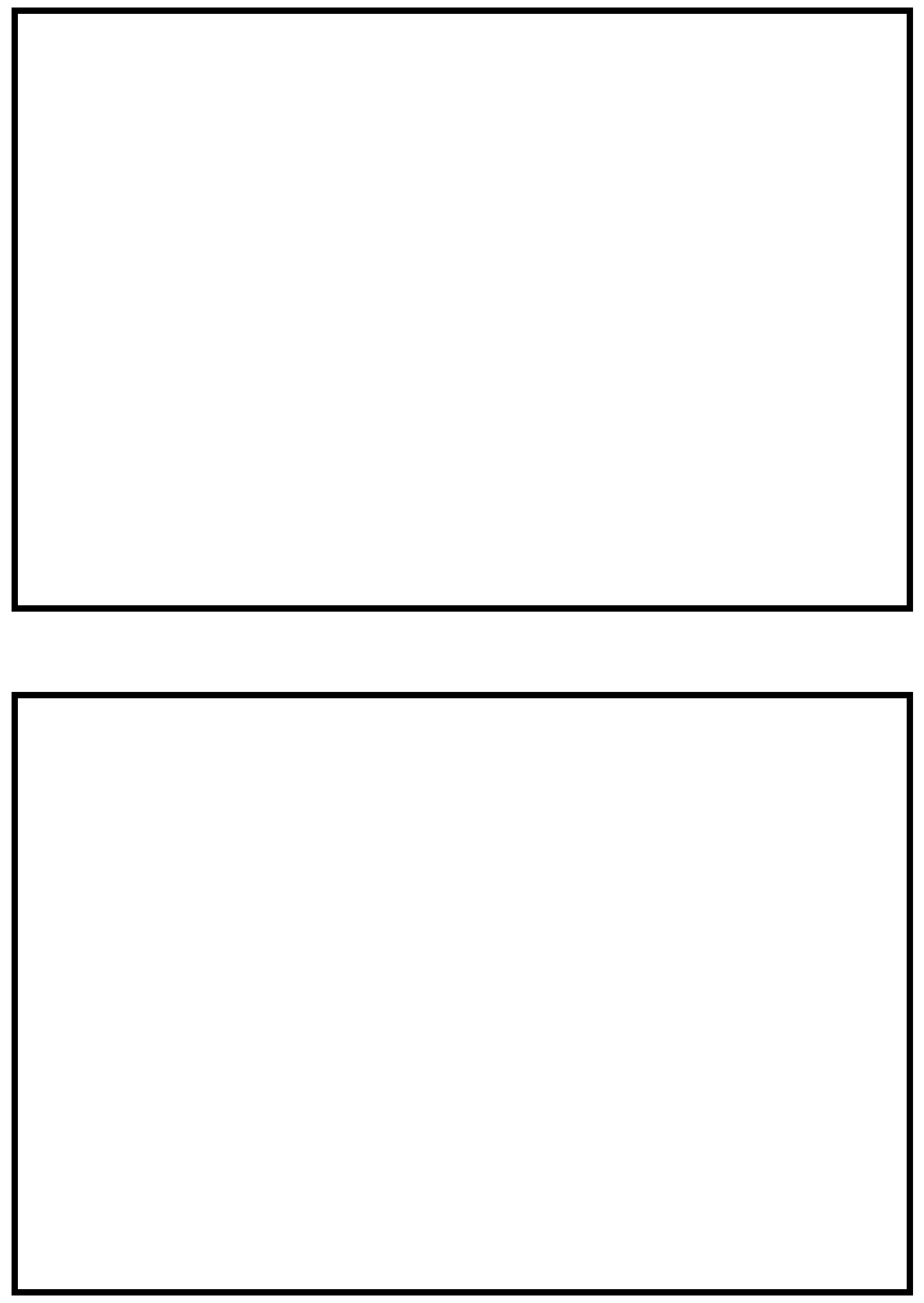

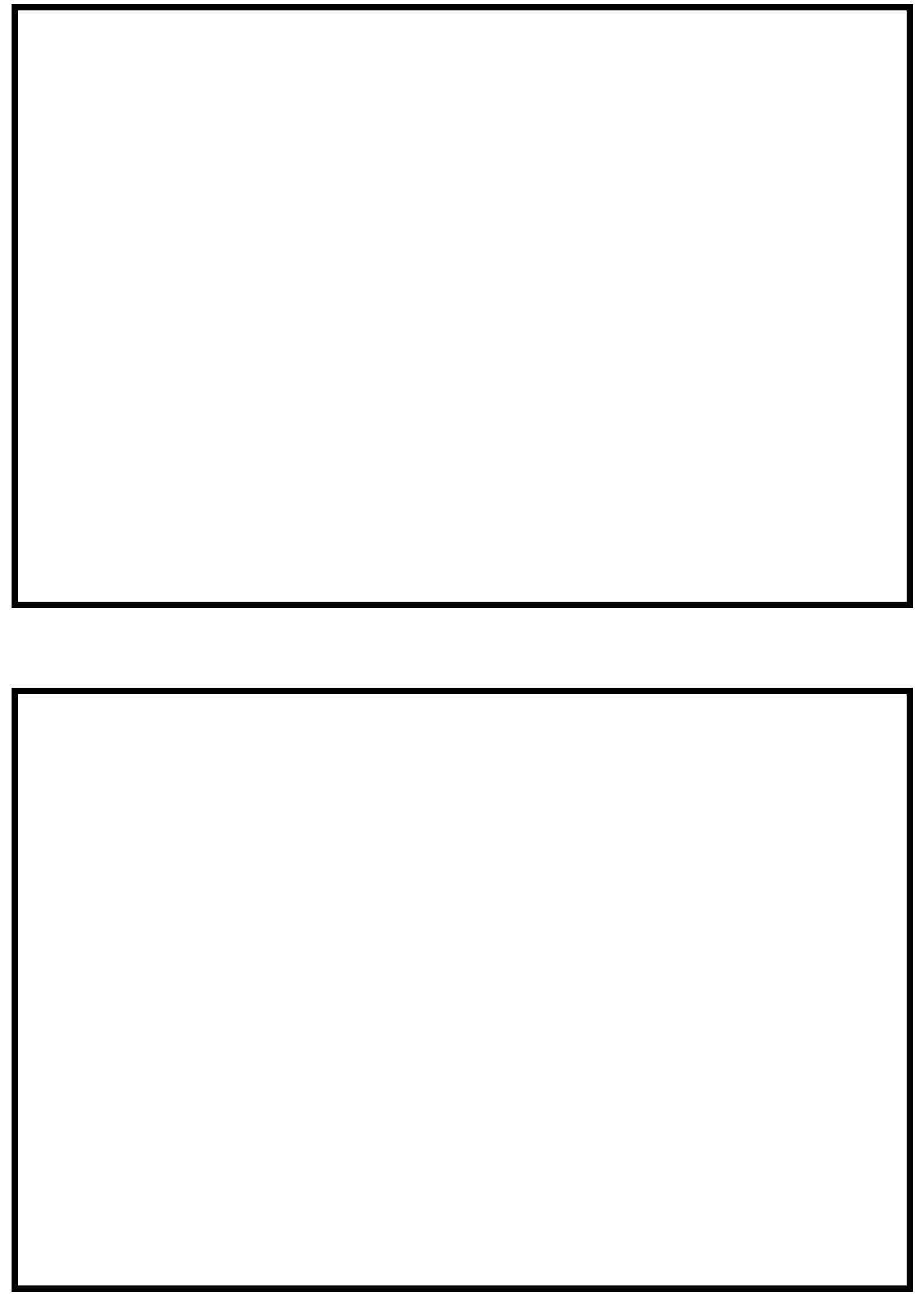


\section{LEVEL II SUMMARY}

\begin{tabular}{llllll} 
& Structure Number & WODSTH00180022 & & \multicolumn{3}{c}{ North Bridgewater Brook } \\
Stream & & & & \\
County & Windsor & Road & TH018 & District & 04 \\
\hline
\end{tabular}

\section{Description of Bridge}

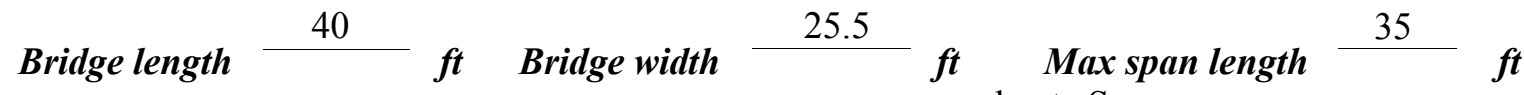
Alignment of bridge to road (on curve or straight) Abutment type Concrete, vertical

Stone fill on abutment?

\section{Embankment type} moderate S-curve

sloping

\section{$08 / 16 / 94$}

nato af insnortinn
Type II around wingwalls. Stone fill is in good condition on

namanintin.. af atam fill

no

wingwalls. Some stone fill is also on abutments but is very sparse and not protecting the

abutment.

\section{Y}

Is bridge skewed to flood flow according to Y r survey?

Angle

The skew angle of the stream to the bridge is 45 degrees. Opening skew to roadway is 30_degrees and the left abutment is attacked at approximately 20 degrees

Debris accumulation on bridge at time of Level I or Level II site visit:

\section{Date of insnortion $08 / 16 / 94$}

Level I

Level II instability of stream

Potential for debris

\section{Percent of ahminal blocked nortzontatly}

same

$--$
Moderate due to high banks with noticeable slip-failure and lateral

On 08/16/94 it was noted that a small boulder point bar exists under the bridge which may

Doscriho anv, foaturos noar ar at tho hridoo that mav affort flow, (includo ahsorvation dato) further constrict flow. Flood flows will impact the left abutment heavily and may cause pile-up of water and increase scour. 


\section{Description of the Geomorphic Setting}

General topography Narrow, incised valley with steep valley walls; road and stream run along valley bottom

Geomorphic conditions at bridge site: downstream (DS), upstream (US)

Date of inspection $\quad 08 / 16 / 94$

DS left: $\quad$ two-lane road, then steep valley wall

DS right: $\quad$ steep valley wall

US left: $\quad$ steep valley wall

US right: $\quad$ two-lane road, then steep valley wall

\section{Description of the Channel}

\begin{tabular}{lllll} 
Average top width & \multicolumn{2}{c}{ f8 } & Average depth & $\frac{7}{\text { gravel }}$ \\
Predominant bed material & cobble & Bank material sinuous, with no
\end{tabular}

flood plains. It is semi-alluvial and laterally unstable

$08 / 16 / 94$

Vegetative co 1 Forest

DS left: $\quad$ Shrub and brush

DS right: Forest

US left: $\quad$ Shrub and brush; road at top of bank.

US right: $\quad \underline{\mathrm{N}}$

Do banks appear stable? 08/16/94--Banks are reported to be steep and eroded by means of slip failures from above the channel. The USLB has stone fill and it is in good condition; the USRB
date of observatton. is protected by stone fill but the fill is eroded in places; the DSLB and DSRB are protected by stone fill and the stone fill is in good condition.

$\underline{08 / 16 / 94--A ~ p o i n t ~ b a r ~}$

exists under the structure.

Describe any obstructions in channel and date of observation. 


\title{
Hydrology
}

Drainage area $\quad 4.34 \quad \boldsymbol{m i}^{2}$

Percentage of drainage area in physiographic provinces: (approximate)

Physiographic province Green Mountain
Percent of drainage area 100

\begin{abstract}
Is drainage area considered rural or urban?
Rural urbanization: None

Describe any significant
\end{abstract}

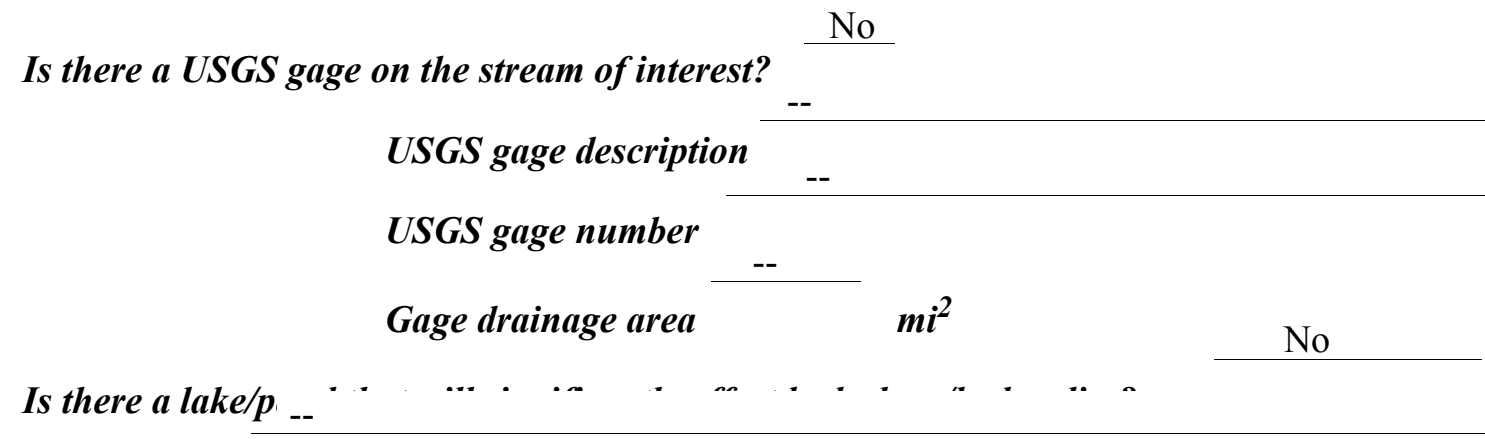

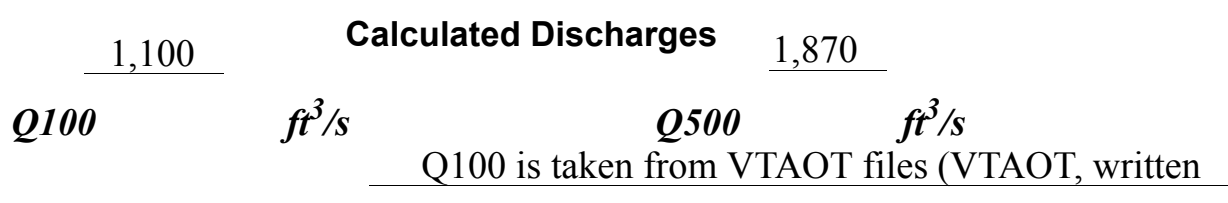

communication, May, 1995). Q500 determined by multiplying Q100 by 1.7 (Richardson and others, 1983) 


\section{Description of the Water-Surface Profile Model (WSPRO) Analysis}

Datum for WSPRO analysis (USGS survey, sea level, VTAOT plans)

USGS survey

Datum tie between USGS survey and VTAOT plans

Subtract 411 feet from VTAOT

datum.

Description of reference marks used to determine USGS datum. $\quad$ RM1 is a chiseled

triangle on top of the DS right wingwall where it meets the right abutment with an arbitrary

survey elevation of 501.27 feet, arbitrary datum

\section{Cross-Sections Used in WSPRO Analysis}

\begin{tabular}{|c|c|c|c|}
\hline${ }^{1}$ Cross-section & $\begin{array}{c}\text { Section } \\
\text { Reference } \\
\text { Distance } \\
\text { (SRD) in feet }\end{array}$ & $\begin{array}{c}{ }^{2} \text { Cross-section } \\
\text { development }\end{array}$ & Comments \\
\hline EXITX & 0 & 1 & Exit section \\
\hline FV & 50 & 2 & $\begin{array}{l}\text { Downstream Full-valley } \\
\text { section (Templated from } \\
\text { EXITX) }\end{array}$ \\
\hline $\mathrm{BRO}$ & 50 & 1 & Bridge section \\
\hline RDWAY & 65 & 1 & Road Grade section \\
\hline APPR & 115 & 2 & $\begin{array}{l}\text { Modelled Approach sec- } \\
\text { tion (Templated from } \\
\text { SURVA) }\end{array}$ \\
\hline SURVA & 135 & 1 & $\begin{array}{l}\text { Approach section as sur- } \\
\text { veyed (Used as a tem- } \\
\text { plate) }\end{array}$ \\
\hline
\end{tabular}

${ }^{1}$ For location of cross-sections see plan-view sketch included with Level I field form, Appendix E.

For more detail on how cross-sections were developed see WSPRO input file. 


\section{Data and Assumptions Used in WSPRO Model}

Hydraulic analyses of the reach were done by use of the Federal Highway Administration's WSPRO step-backwater computer program (Shearman and others, 1986, and

Shearman, 1990). Results of the hydraulic model are presented in the Bridge Hydraulic Summary, Appendix B, and figure 7.

Channel roughness factors (Manning's " $\mathrm{n}$ ") used in the hydraulic model were estimated using field inspections at each cross section following the general guidelines described by Arcement, Jr. and Schneider (1989). Final adjustments to the values were made during the modelling of the reach. Channel " $\mathrm{n}$ " values for the reach ranged from 0.064 to 0.065 .

Normal depth at the exit section (EXITX) was assumed as the starting water surface. This depth was computed by use of the slope-conveyance method outlined in the User's manual for WSPRO (Shearman, 1990). The slope used was $0.038 \mathrm{ft} / \mathrm{ft}$ which was determined from surveyed thalweg points downstream of the bridge.

The surveyed approach section (SURVA) was moved along the approach channel slope $(0.03 \mathrm{ft} / \mathrm{ft})$ to establish the modelled approach section (APPR), one bridge length upstream of the upstream face as recommended by Shearman and others (1986). This approach also provides a consistent method for determining scour variables.

In the unconstricted hydraulic model through the reach, the energy equation was not balanced between the FV and APPR sections, and the APPR section defaulted to critical depth. The default to critical depth was allowed since additional analyses indicated that flow in the unconstricted model run would indeed be close to critical depth. 


\title{
Bridge Hydraulics Summary
}

\author{
Average bridge embankment elevation $\quad 501.4 \quad f t$ \\ Average low steel elevation \\ $499.1 \quad f t$
}

100-year discharge $\quad 1,100 \quad \mathrm{ft}^{3} / \mathrm{s}$

Water-surface elevation in bridge opening $\quad \begin{aligned} & 492.8 \quad f t \\ & \end{aligned}$

Road overtopping? __ no Discharge over road __ _ -

Area of flow in bridge opening $\quad 114 \quad \mathrm{ft}^{2}$

Average velocity in bridge opening $\quad \begin{array}{lll}9.6 & \mathrm{ft} / \mathrm{s}\end{array}$

Maximum WSPRO tube velocity at bridge $11.3 \mathrm{ft} / \mathrm{s}$

Water-surface elevation at Approach section with bridge 495.4

Water-surface elevation at Approach section without bridge $\quad 494.8$

Amount of backwater caused by bridge $\quad 0.6$ it

500-year discharge $\quad 1,870 \quad \mathrm{ft}^{3} / \mathrm{s}$

Water-surface elevation in bridge opening

$493.9 f t$

Road overtopping? __ no Discharge over road ___

Area of flow in bridge opening $\quad 145 \quad \mathrm{ft}^{2}$

Average velocity in bridge opening $\quad 12.9 \mathrm{ft} / \mathrm{s}$

Maximum WSPRO tube velocity at bridge 15.4_'s

Water-surface elevation at Approach section with bridge 498.6

Water-surface elevation at Approach section without bridge $\quad 496.3$

Amount of backwater caused by bridge 2.3 .

Incipient overtopping discharge ___ _- $\mathrm{ft}^{3} / \mathrm{s}$

Water-surface elevation in bridge opening $\quad--\quad t$

Area of flow in bridge opening _ - _ $\mathrm{ft}^{2}$

Average velocity in bridge opening $\quad--\quad f t / s$

Maximum WSPRO tube velocity at bridge $\quad--\quad f t / s$

Water-surface elevation at Approach section with bridge

Water-surface elevation at Approach section without bridge

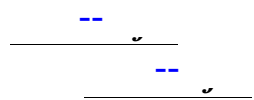

Amount of backwater caused by bridge _ $\quad-{ }_{-}$, t 


\section{Scour Analysis Summary}

\section{Special Conditions or Assumptions Made in Scour Analysis}

Scour depths were computed using the general guidelines described in Hydraulic Engineering Circular 18 (Richardson and others, 1993). Scour depths were calculated assuming an infinite depth of erosive material and a homogeneous particle-size distribution. The results of the scour analysis are presented in tables 1 and 2 and a graph of the scour depths is presented in figure 8 .

Contraction scour for the 100-year and 500-year discharge was computed by use of the clear-water equation (Richardson and others, 1993, p. 35, equation 18) because the mean velocity in the channel was slightly lower than the critical velocity. For contraction scour computations, the average depth in the contracted section (AREA/TOPWIDTH) is subtracted from the depth of flow computed by the scour equation (Y2) to determine the actual amount of scour.

Abutment scour was computed by use of the Froehlich equation (Richardson and others, 1993, p. 49, equation 24). The Froehlich equation gives "excessively conservative estimates of scour depths" (Richardson and others, 1993, p. 48). Variables for the Froehlich equation include the Froude number of the flow approaching the embankments, the length of the embankment blocking flow, and the depth of flow approaching the embankment less any roadway overtopping. 


\section{Scour Results}

\section{0-yr discharge 500-yr discharge}

Contraction scour:

(Scour depths in feet)

Main channel

Live-bed scour

Clear-water scour

Depth to armoring

Left overbank

Right overbank

Local scour:

Abutment scour

Left abutment

8.5

$--$

5.3

Right abutment

Pier scour

Pier 1

Pier 2

6.9

Pier 3
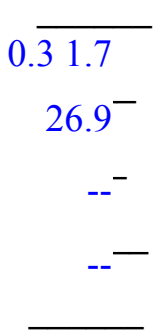
overtopping discharge

Incipient 


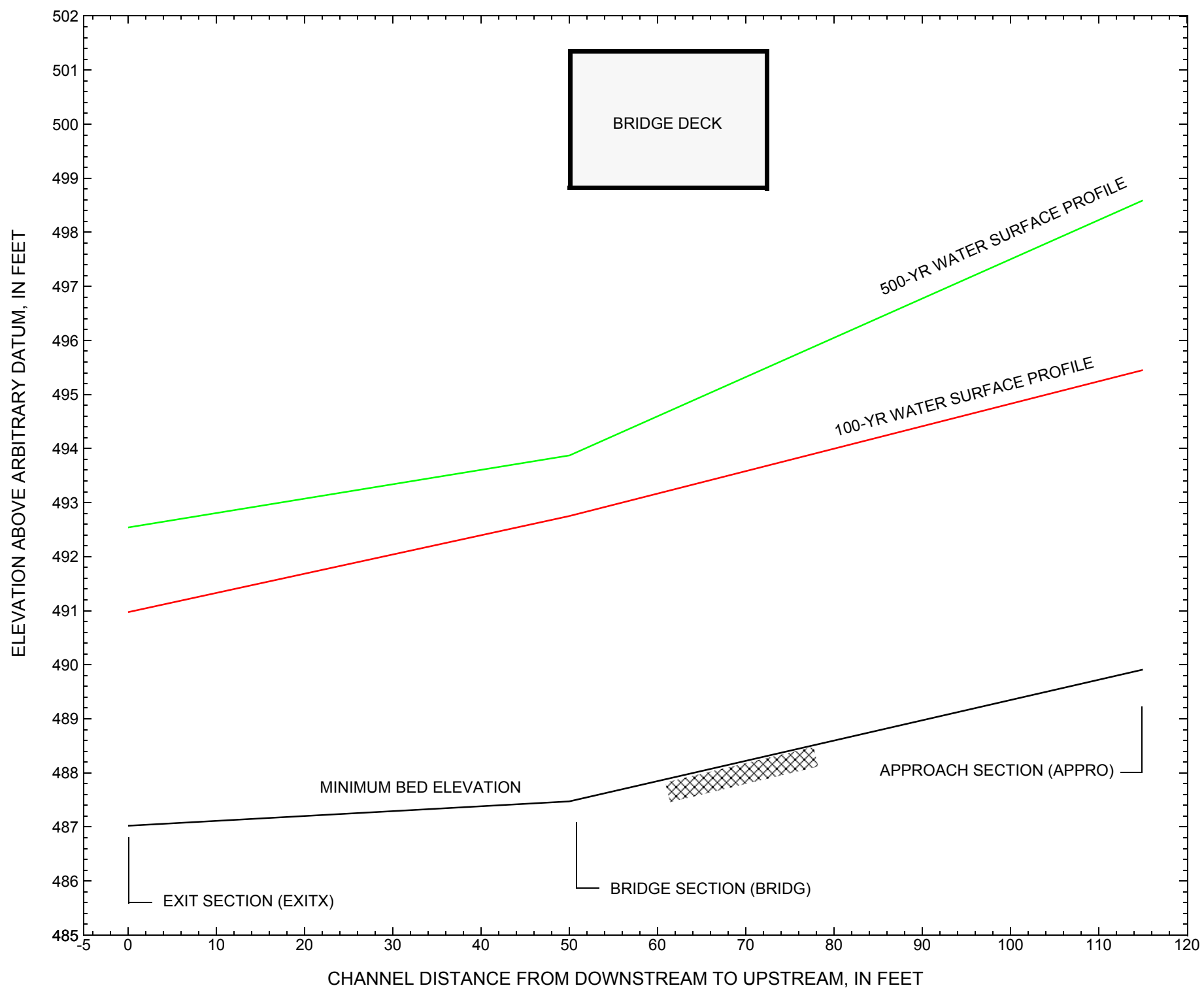

Figure 7. Water-surface profiles for the 100- and 500-yr discharges at structure WODSTH00180022 on town highway 18, crossing North Bridgewater Brook, Woodstock, Vermont. 


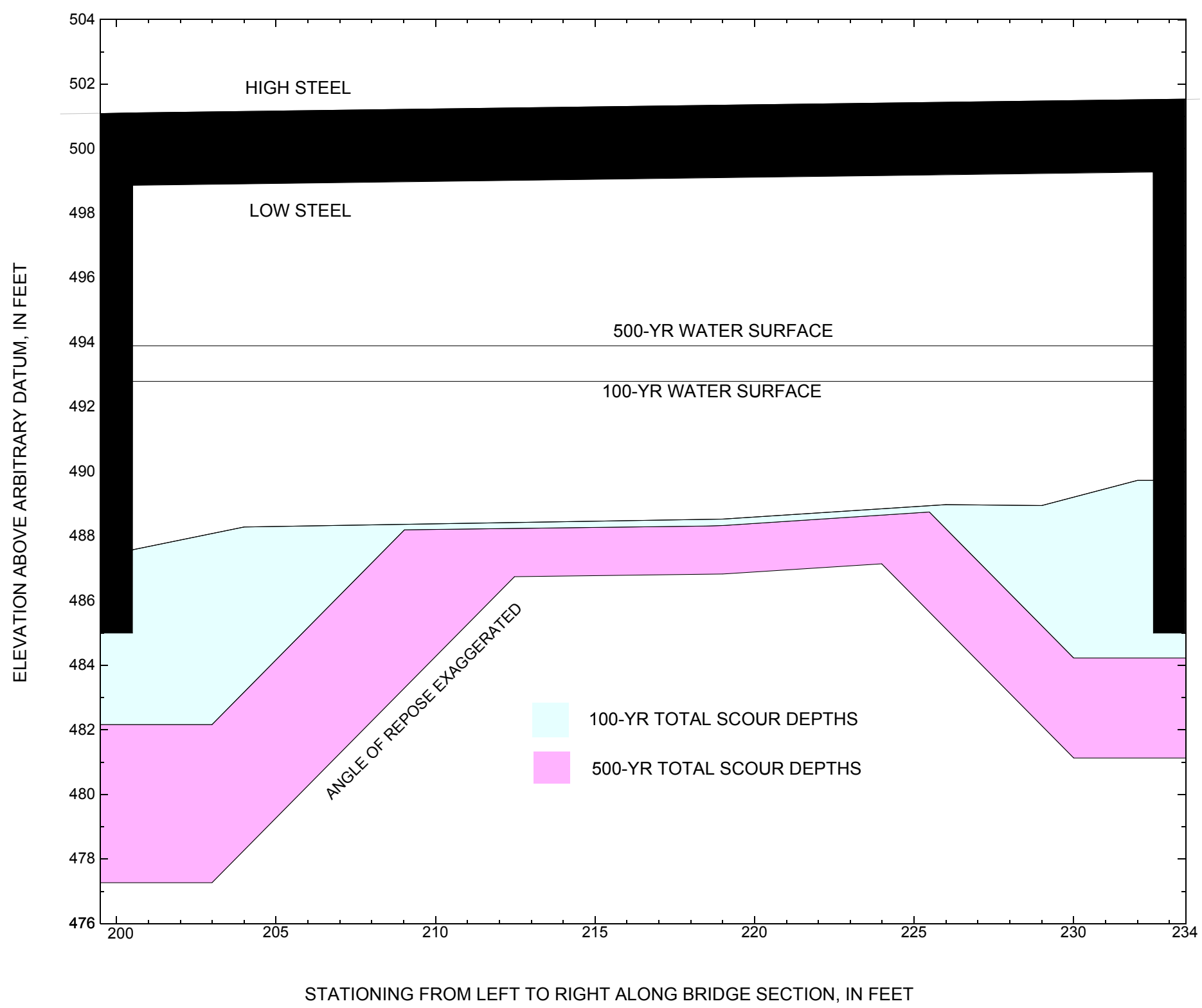

Figure 8. Scour elevations for the 100-yr and 500-yr discharges at structure WODSTH00180022 on town highway 18, crossing North Bridgewater Brook, Woodstock, Vermont. 
Table 1. Remaining footing/pile depth at abutments for the 100-year discharge at structure WODSTH00180022 on Town Highway 18, crossing North Bridgewater Brook, Woodstock, Vermont.

[VTAOT, Vermont Agency of Transportation; --,no data]

\begin{tabular}{|c|c|c|c|c|c|c|c|c|c|c|c|}
\hline Description & Station $^{1}$ & $\begin{array}{l}\text { VTAOT } \\
\text { plans' } \\
\text { bridge seat } \\
\text { elevation } \\
\text { (feet) }\end{array}$ & $\begin{array}{l}\text { Surveyed } \\
\text { minimum } \\
\text { low-chord } \\
\text { elevation } \\
\text { (feet) }\end{array}$ & $\begin{array}{c}\text { Bottom of } \\
\text { footing } \\
\text { elevation } \\
\text { (feet) }\end{array}$ & $\begin{array}{c}\text { Channel } \\
\text { elevation at } \\
\text { abutment/ } \\
\text { pier }^{2} \\
\text { (feet) }\end{array}$ & $\begin{array}{l}\text { Contraction } \\
\text { scour depth } \\
\text { (feet) }\end{array}$ & $\begin{array}{l}\text { Abutment } \\
\text { scour } \\
\text { depth } \\
\text { (feet) }\end{array}$ & $\begin{array}{l}\text { Pier } \\
\text { scour } \\
\text { depth } \\
\text { (feet) }\end{array}$ & $\begin{array}{c}\text { Depth of } \\
\text { total scour } \\
\text { (feet) }\end{array}$ & $\begin{array}{c}\text { Elevation of } \\
\text { scour }^{2} \\
\text { (feet) }\end{array}$ & $\begin{array}{c}\text { Remaining } \\
\text { footing/pile } \\
\text { depth } \\
\text { (feet) }\end{array}$ \\
\hline \multicolumn{12}{|c|}{100 -yr. discharge is 8,030 cubic-feet per second } \\
\hline Left abutment & 200 & 910.1 & 498.8 & 485 & 487.5 & 0.3 & 5.1 & -- & 5.4 & 482.1 & -3 \\
\hline Right abutment & 233 & 910.6 & 499.3 & 485 & 489.7 & 0.3 & 5.3 & -- & 5.6 & 484.1 & -1 \\
\hline
\end{tabular}

1. Measured along the face of the most constricting side of the bridge.

2. Arbitrary datum for this study.

Table 2. Remaining footing/pile depth at abutments for the 500-year discharge at structure WODSTH00180022 on Town Highway 18, crossing North Bridgewater Brook, Woodstock, Vermont.

[VTAOT, Vermont Agency of Transportation; --, no data]

\begin{tabular}{|c|c|c|c|c|c|c|c|c|c|c|c|}
\hline Description & Station $^{1}$ & $\begin{array}{l}\text { VTAOT } \\
\text { plans' } \\
\text { bridge seat } \\
\text { elevation } \\
\text { (feet) }\end{array}$ & $\begin{array}{l}\text { Surveyed } \\
\text { minimum } \\
\text { low-chord } \\
\text { elevation } \\
\quad \text { (feet) }\end{array}$ & $\begin{array}{l}\text { Bottom of } \\
\text { footing } \\
\text { elevation } \\
\text { (feet) }\end{array}$ & $\begin{array}{c}\text { Channel } \\
\text { elevation at } \\
\text { abutment/ } \\
\text { pier }^{2} \\
\text { (feet) }\end{array}$ & $\begin{array}{l}\text { Contraction } \\
\text { scour depth } \\
\text { (feet) }\end{array}$ & $\begin{array}{l}\text { Abutment } \\
\text { scour } \\
\text { depth } \\
\text { (feet) }\end{array}$ & $\begin{array}{l}\text { Pier } \\
\text { scour } \\
\text { depth } \\
\text { (feet) }\end{array}$ & $\begin{array}{l}\text { Depth of } \\
\text { total scour } \\
\text { (feet) }\end{array}$ & $\begin{array}{c}\text { Elevation of } \\
\text { scour }^{2} \\
\text { (feet) }\end{array}$ & $\begin{array}{c}\text { Remaining } \\
\text { footing/pile } \\
\text { depth } \\
\text { (feet) }\end{array}$ \\
\hline \multicolumn{12}{|c|}{500 -yr. discharge is 11,600 cubic-feet per second } \\
\hline Left abutment & 200 & 910.1 & 498.8 & 485 & 487.5 & 1.7 & 8.5 & -- & 10.2 & 477.3 & -9 \\
\hline Right abutment & 233 & 910.6 & 499.3 & 485 & 489.7 & 1.7 & 6.9 & -- & 8.6 & 481.1 & -5 \\
\hline
\end{tabular}

1. Measured along the face of the most constricting side of the bridge.

2. Arbitrary datum for this study. 


\section{SELECTED REFERENCES}

Arcement, G.J., Jr., and Schneider, V.R., 1989, Guide for selecting Manning's roughness coefficients for natural channels and flood plains: U.S. Geological Survey Water-Supply Paper 2339, 38 p.

Barnes, H.H., Jr., 1967, Roughness characteristics of natural channels: U.S. Geological Survey Water-Supply Paper 1849, 213 p.

Brown, S.A. and Clyde, E.S., 1989, Design of riprap revetment: Federal Highway Administration Hydraulic Engineering Circular No. 11, Publication FHWA-IP-89-016, 156 p.

Froehlich, D.C., 1989, Local scour at bridge abutments in Ports, M.A., ed., Hydraulic Engineering--Proceedings of the 1989 National Conference on Hydraulic Engineering: New York, American Society of Civil Engineers, p. 13-18.

Hayes, D.C.,1993, Site selection and collection of bridge-scour data in Delaware, Maryland, and Virginia: U.S. Geological Survey Water-Resources Investigation Report 93-4017, 23 p.

Johnson, C.G. and Tasker, G.D.,1974, Progress report on flood magnitude and frequency of Vermont streams: U.S. Geological Survey Open-File Report 74-130, 37 p.

Laursen, E.M., 1960, Scour at bridge crossings: Journal of the Hydraulics Division, American Society of Civil Engineers, v. 86, no. HY2, p. 39-53.

Richardson, E.V., Harrison, L.J., Richardson, J.R., and Davis, S.R., 1993, Evaluating scour at bridges: Federal Highway Administration Hydraulic Engineering Circular No. 18, Publication FHWA-IP-90-017, 131 p.

Richardson, E.V., Simons, D.B., and Julien, P.Y., 1990, Highways in the river environment: Federal Highway Administration Publication FHWA-HI-90-016.

Ritter, D.F., 1984, Process Geomorphology: W.C. Brown Co., Debuque, Iowa, 603 p.

Shearman, J.O., 1990, User's manual for WSPRO--a computer model for water surface profile computations: Federal Highway Administration Publication FHWA-IP-89-027, 187 p.

Shearman, J.O., Kirby, W.H., Schneider, V.R., and Flippo, H.N., 1986, Bridge waterways analysis model; research report: Federal Highway Administration Publication FHWA-RD-86-108, 112 p.

U.S. Department of Transportation, 1993, Stream stability and scour at highway bridges, Participant Workbook: Federal Highway Administration Publication FHWA HI-91-011.

U.S. Geological Survey, 1966, Woodstock North, Vermont 7.5 Minute Series quadrangle map: U.S. Geological Survey Topographic Maps, Scale 1:24,000. 


\section{APPENDIX A: \\ WSPRO INPUT FILE}




\section{WSPRO INPUT FILE}

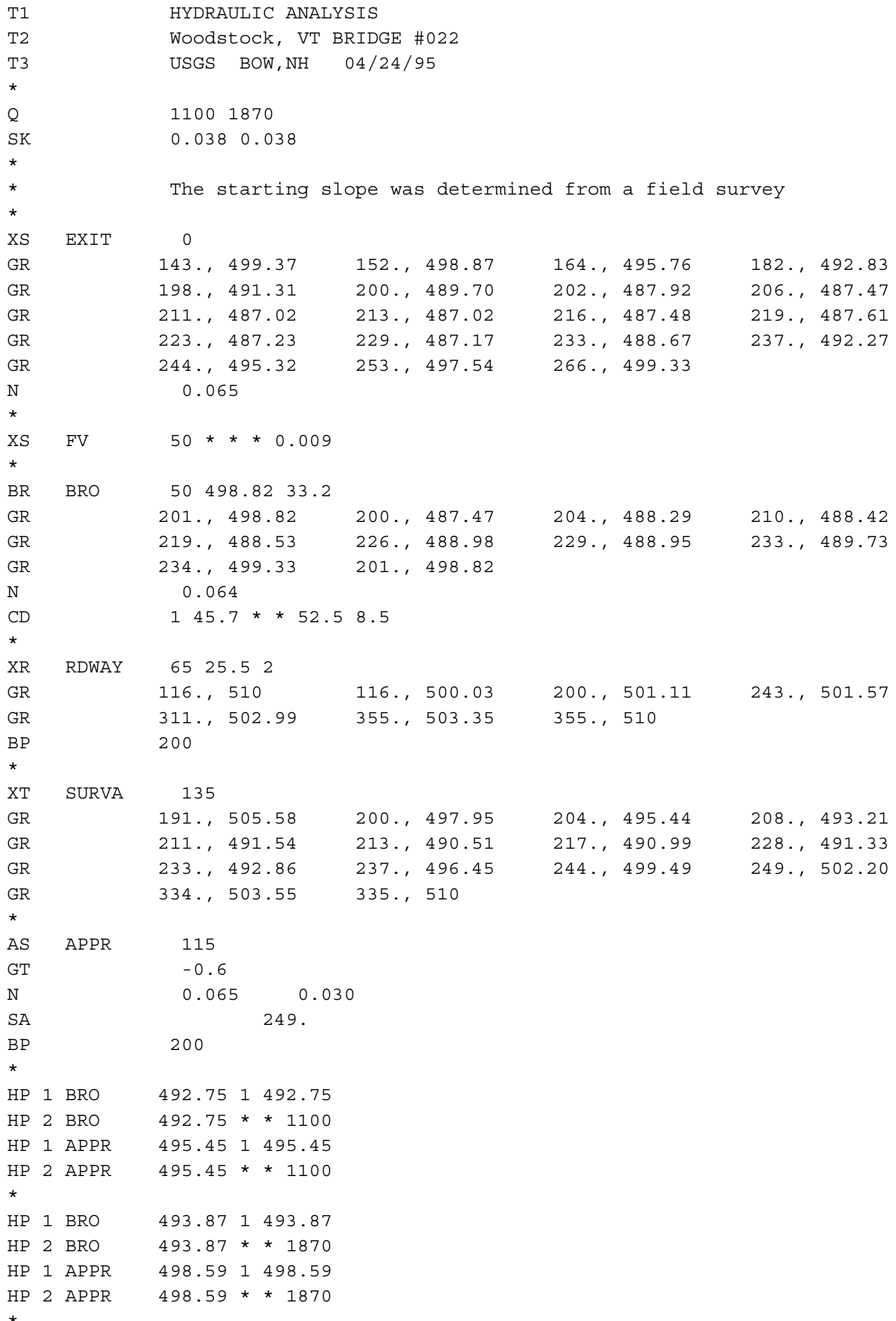




\section{APPENDIX B: \\ WSPRO OUTPUT FILE}


WSPRO OUTPUT FILE

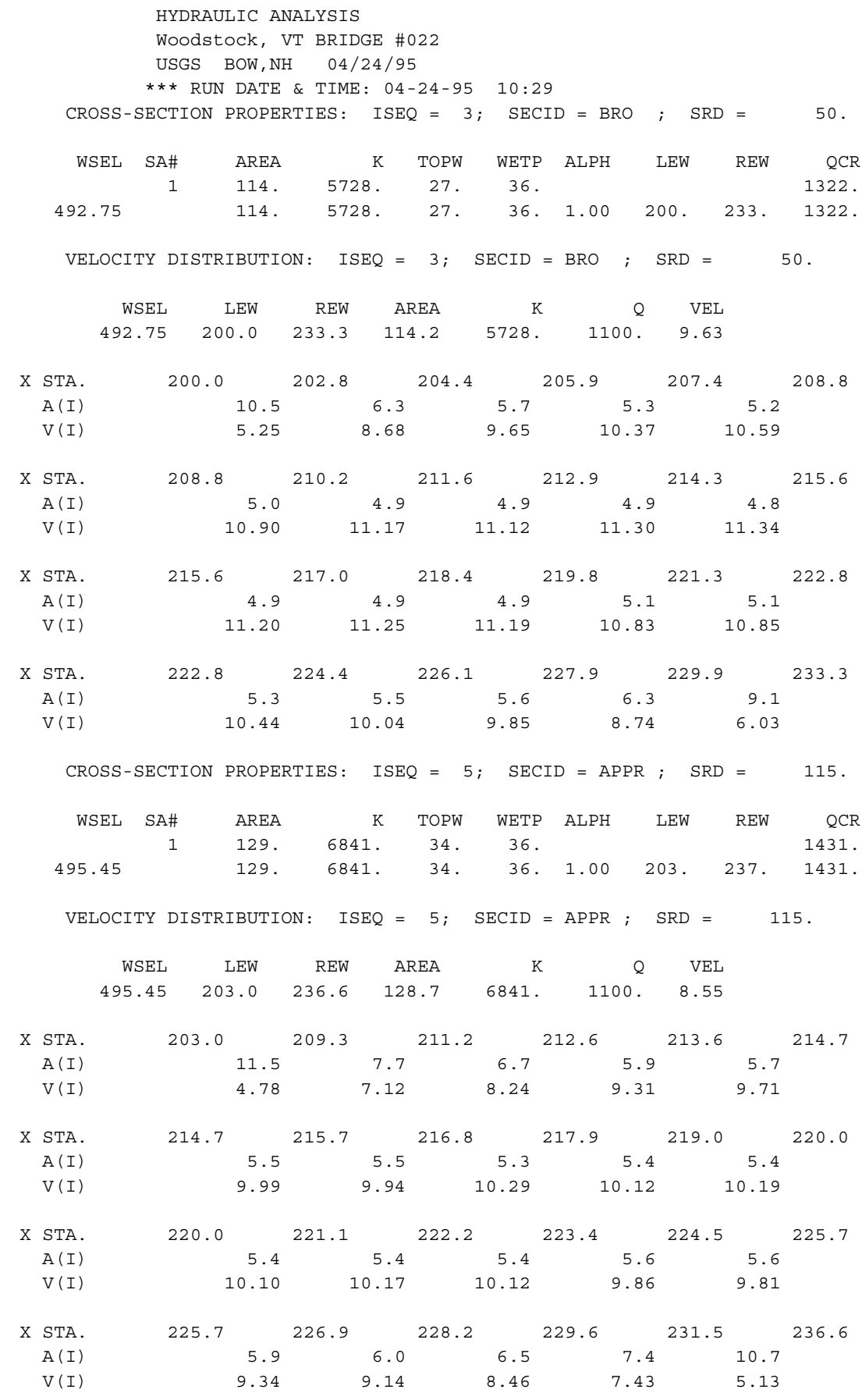


WSPRO OUTPUT FILE (continued)

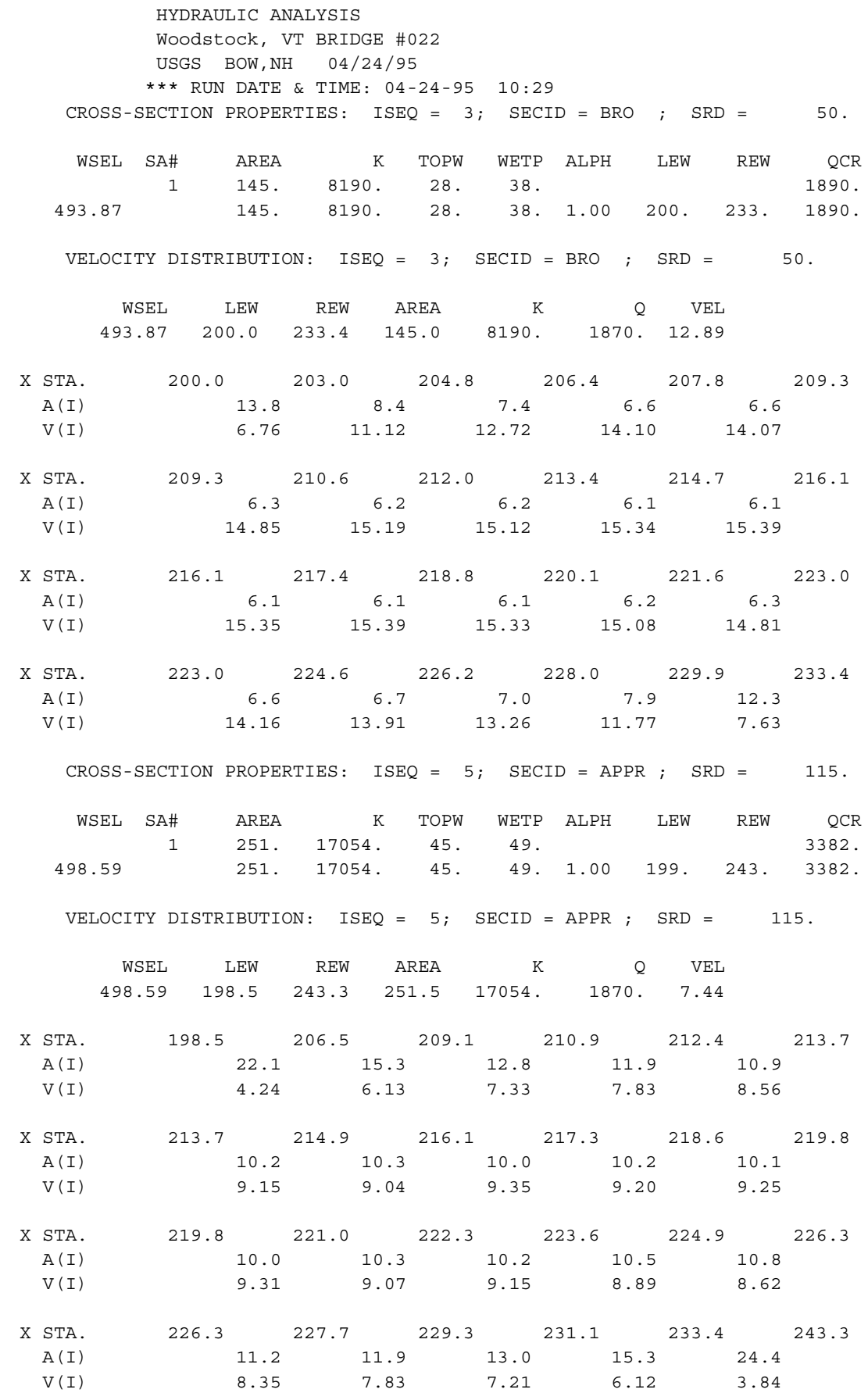




\section{WSPRO OUTPUT FILE (continued)}

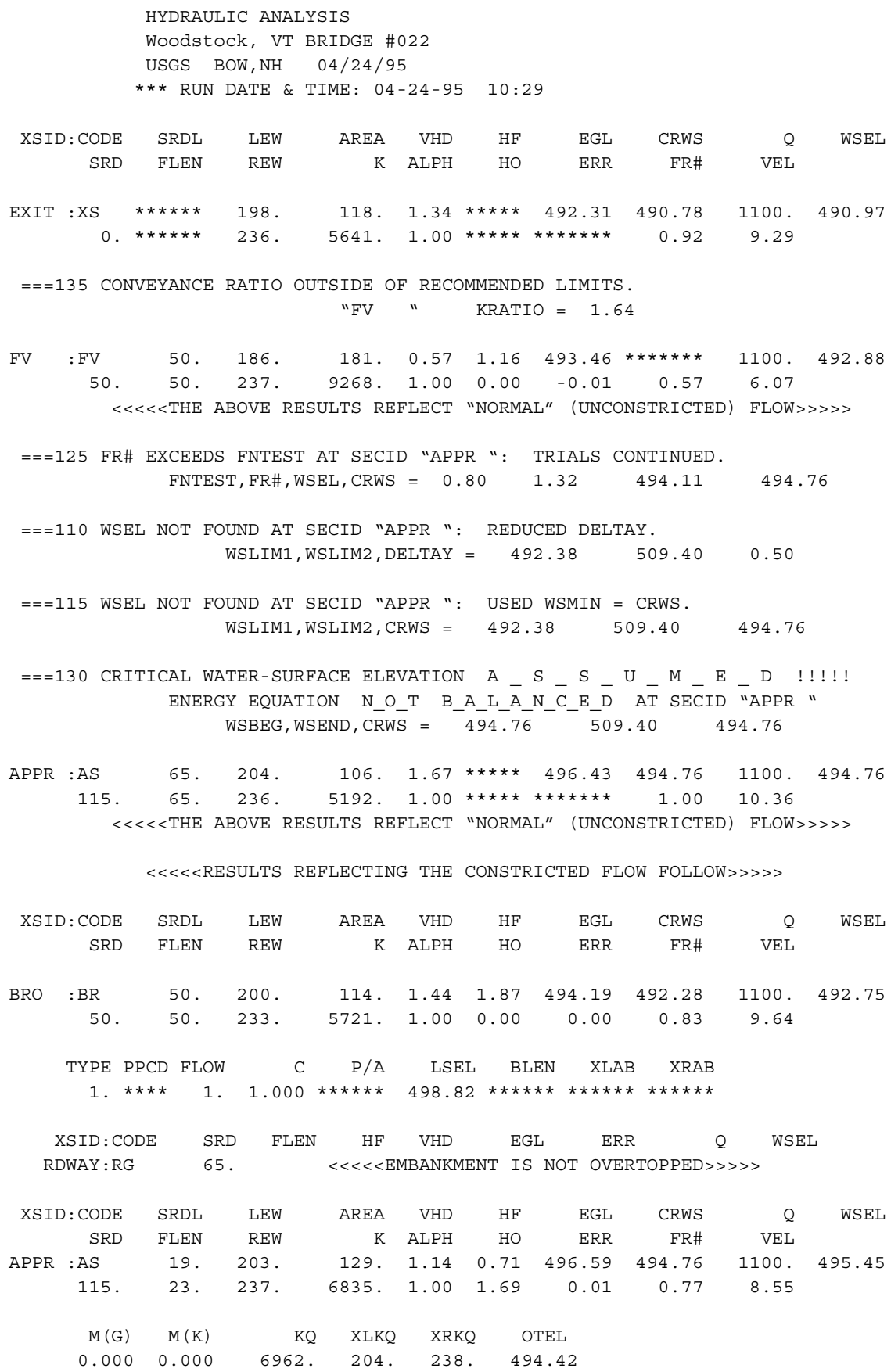




\section{WSPRO OUTPUT FILE (continued)}

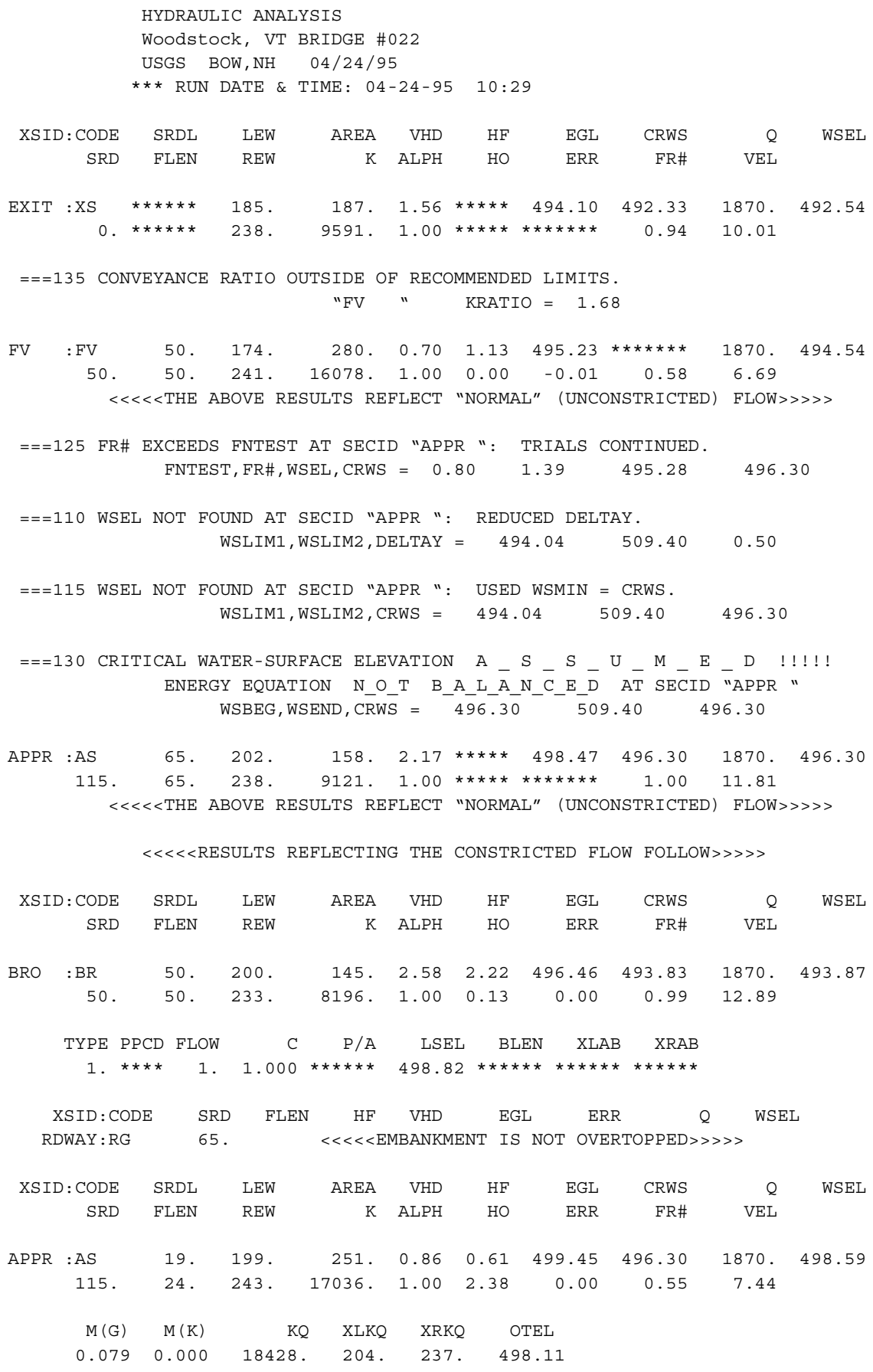




\section{APPENDIX C:}

\section{BED-MATERIAL PARTICAL-SIZE DISTRIBUTION}




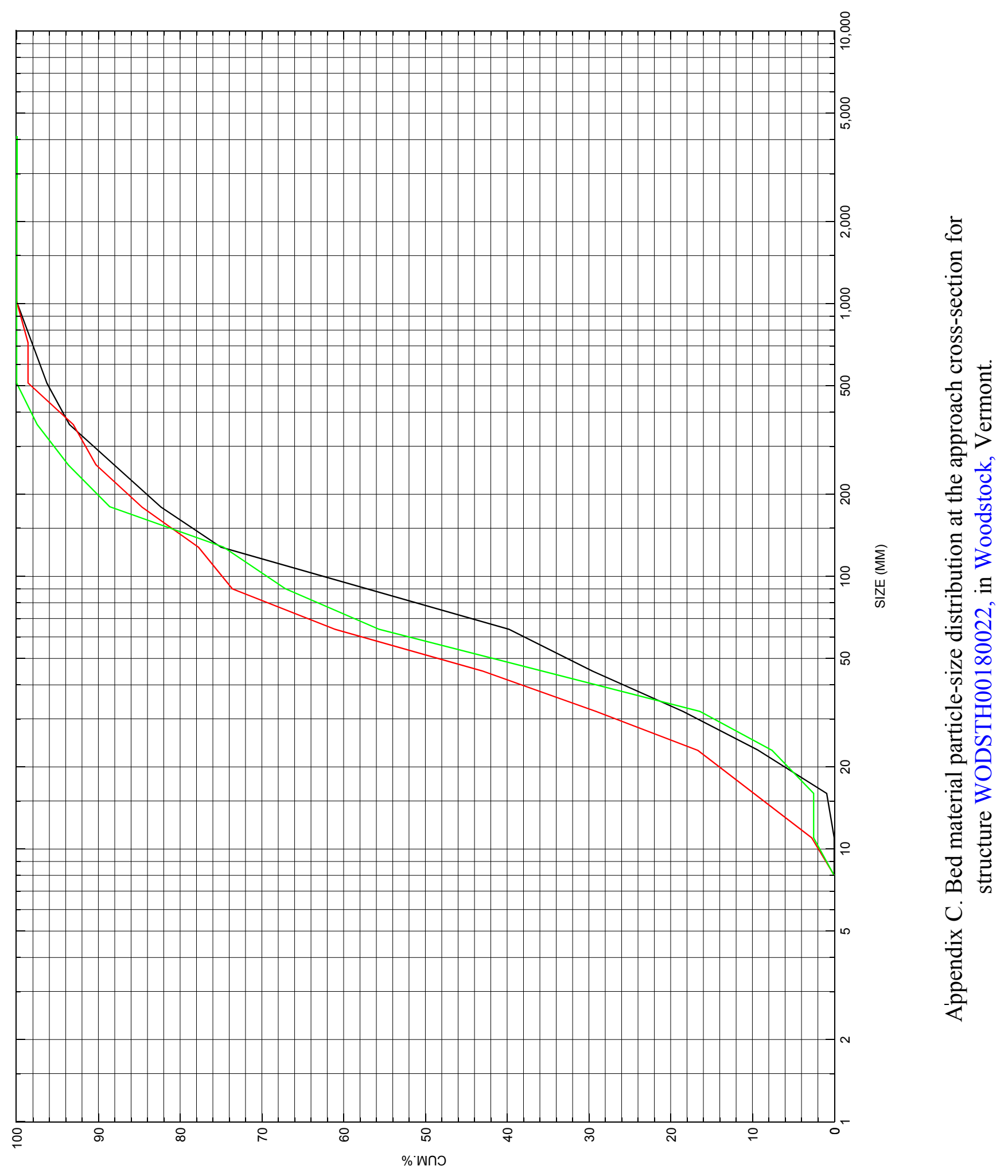




\section{APPENDIX D: \\ HISTORICAL DATA FORM}

